\title{
Linkage between land use patterns and sediment phosphorus sorption behaviors along shoreline of a Chinese large shallow lake (Lake Chaohu)
}

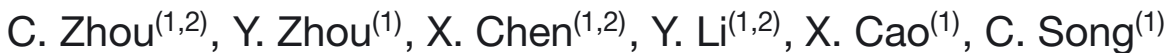

Received March 9, 2011

Revised April 22, 2011

Accepted July 18, 2011

\section{ABSTRACT}

Key-words: degree of phosphorus saturation, phosphorus sorption behavior, land use, sediment, soil
To test the relationship between phosphorus buffering capacity in sediments of littoral zone and land use, seasonal samples were taken from the soils representing different patterns of land use, together with the littoral zone sediments, along shoreline in Lake Chaohu. There existed significantly positive relationships between equilibrium phosphorus concentration $\left(\mathrm{EPC}_{0}\right)$ and degree of phosphorus saturation (DPS) defined as ratios of Olsen-P, algae available phosphorus (AAP) and inorganic phosphorus (IP) to maximum sorption capacity $\left(Q_{\max }\right)$. So, some easily accessible $P$ parameters especially DPS were indicative of $\mathrm{EPC}_{0}$ in the sediments. Furthermore, the contents of IP, total phosphorus (TP) and organic matter (OM) in the sediments were significantly related to those in the soils. Therefore, the soils could provide the littoral zone with IP either directly or indirectly through TP input; it also provided the Olsen-P through the OM input, as evidenced by the relationship between Olsen-P and OM. It meant that the enhanced OM would enlarge the DPS. On the other hand, the increase in OM paralleled with the increases in $Q_{\max }$, which lower the DPS simultaneously. Thus, the OM modified sediment phosphorus sorption behaviors in complicated manners. Finally, the soil covered by Fleabane was coupled with the sediment whose EPC $\mathrm{C}_{0}$ values were lower and further decreased with strong diffusion from the soils after heavy rains. Hence, shoreline soil may input TP including IP and OM into the lake and alter the DPS together with $\mathrm{EPC}_{0}$ thereby regulating the sediment functions to act as sink or source of phosphorus.

\section{RÉSUMÉ}

Lien entre les modes d'utilisation des terres et le comportement de sorption du phosphore des sédiments le long du littoral d'un lac peu profond en Chine (lac Chaohu)

Mots-clés : degré de saturation en phosphore, comportement de sorption $d u$ phosphore, utilisation des terres, sédiments, sols
Afin de tester la relation entre la capacité tampon phosphore des sédiments de la zone littorale et l'utilisation des terres, des échantillons de sols représentant différents modes d'utilisation des terres ont été prélevés saisonnièrement en même temps que des sédiments en zone littorale, le long des rives du lac Chaohu. II existe des relations significativement positives entre la concentration de phosphore à l'équilibre (EPC) et le degré de saturation en phosphore (DPS) défini comme les ratios du Olsen-P, du phosphore disponible aux algues (PAA) et du phosphore inorganique (IP) à un maximum de capacité de sorption $\left(Q_{\max }\right)$. Ainsi, certains paramètres facilement accessibles du $\mathrm{P}$, en particulier DPS sont indicatifs d'EPC ${ }_{0}$ dans les sédiments. Par ailleurs, le contenu en phosphore inorganique (IP), le phosphore total (TP) et la matière organique (OM) dans les sédiments sont

(1) Institute of Hydrobiology, the Chinese Academy of Sciences, Wuhan 430072, P.R. China, clsong@ihb.ac.cn

(2) Graduate School of the Chinese Academy of Sciences, Beijing 100039, P.R. China 
significativement corrélés à ceux des sols. Par conséquent, les sols fournissent la zone littorale en IP directement ou indirectement par l'intermédiaire des entrées en TP ; de même que le Olsen-P est apporté par l'OM , comme en témoigne la relation entre Olsen-P et l'OM. Cela signifie que l'augmentation de l'OM accroît le DPS. D'autre part, l'augmentation de l'OM en parallèle avec l'augmentation du $Q_{\max }$ abaissent le DPS simultanément. Ainsi, l'OM modifie le comportement de sorption du phosphore des sédiments de manière compliquée. Enfin, le sol couvert par la vergerette est lié à des sédiments dont les valeurs $\mathrm{EPC}_{0}$ sont les plus basses et de plus diminuant par forte diffusion à partir des sols après de fortes pluies. Ainsi, le sol rivulaire peut apporter TP, dont IP et OM dans le lac et modifier le DPS et l'EPC ${ }_{0}$ régulant ainsi les fonctions puits ou source de phosphore des sédiments.

\section{INTRODUCTION}

Phosphorus loss from terrestrial to the aquatic ecosystems contributes to eutrophication of surface waters. To maintain the world's vital freshwater ecosystems, the reduction of eutrophication is crucial (Pothig et al., 2010). The equilibrium phosphorus concentration $\left(\mathrm{EPC}_{0}\right)$ of river bed sediments has been measured for a wide range of agricultural subcatchments and main river sites to examine whether bed sediments are acting as sources or sinks of soluble reactive phosphorus (SRP). Under baseflow conditions, high SRP concentrations from sewage effluent in the tributaries appear to "swamp out" any potential release of SRP from the bed sediments. For rivers that are subject to effluent P-stripping, reductions in SRP in the overlying water could potentially result in changes to the in-stream $\mathrm{P}$-cycling mechanisms, with bed sediments possibly switching from net sinks to net sources of SRP (Jarvie et al., 2005). Moreover, land use and dynamic river conditions had interactions on sorption equilibria between benthic sediments and river SRP concentrations (Stutter and Lumsdon, 2008). Obviously, like river bed, the littoral zone of lake would receive great phosphorus input especially from diffusive sources. As a consequence, the functions of its sediments to act as sink or source of phosphorus must be greatly affected by the land use along the shoreline, which could be estimated by the EPC $\mathrm{E}_{0}$ values. However, the information on this subject is almost lacking. Additionally, phosphorus sorption behaviors were closely related to some environment variable such as the degree of phosphorus saturation (DPS) and organic matter (OM) contents. For example, the investigation of more than 400 soil samples revealed coherent relationships between DPS and $\mathrm{EPC}_{0}$ (Pothig et al., 2010), while most of the relevant investigations were limited to soils. Besides, there were some controversies over the effects of OM on phosphorus sorption behaviors in soils. The phosphorus sorption capacity (Li et al., 2007) and maximum buffer capacity (Subramaniam and Singh, 1997) were positively and highly related to the OM contents. Contrastingly, maximum sorption capacity $\left(Q_{\max }\right)$ was inversely correlated with OM (Janardhanan and Daroub, 2010). Moreover, removal of OM increased or decreased phosphorus sorption depending on the equilibrium $\mathrm{pH}$ values and soil types (Hiradate and Uchida, 2004). Thus, it is desirable to check the role of OM in modifying phosphorus sorption behaviors in lake sediments.

In this study, spatial and seasonal samples were taken from the soils representing the different patterns of land use (agricultural field, grassland, woods) and bank types (dilapidated embankment, rocky embankment and cement embankment) along the shoreline of a Chinese large shallow lake, and the sediments in littoral zones that directly receive diffusion from these soils were also sampled. The contents of organic matter and different phosphorus species in the soils and sediments were measured, and phosphorus sorption behaviors were analyzed in the sediments. The aims of this study were: (1) further examine the effects of organic matter on phosphorus sorption behaviors in lake sediment, (2) connect the variables indicating phosphorus loadings such as DPS with sorption parameters $\left(\mathrm{EPC}_{0}\right)$ and $(3)$ test the hypothesis that the diverse bank type and land use would shape the phosphorus sorption capacity of 
the sediment in littoral zone by diffusing phosphorus and organic matter that differed quantitatively and qualitatively into lakes.

\section{MATERIALS AND METHODS}

\section{> STUDY AREA DESCRIPTION}

Lake Chaohu $\left(117^{\circ} 16^{\prime} 54^{\prime \prime}-117^{\circ} 51^{\prime} 46^{\prime \prime} \mathrm{E}\right.$ and $\left.31^{\circ} 25^{\prime} 28^{\prime \prime}-31^{\circ} 43^{\prime} 28^{\prime \prime} \mathrm{N}\right)$, one of the five largest freshwater lakes in China, is located in the Yangtze-Huaihe region, central of Anhui Province. Its surface area is about $780 \mathrm{~km}^{2}$, drainage total area is $13486 \mathrm{~km}^{2}$, and the shoreline length around the whole lake is $184.66 \mathrm{~km}$. The basic limnological data were given by $\mathrm{Xu}$ et al. (2005). In the last decades, the disturbance from human was becoming increasingly serious and made the shoreline of the lake shrink a lot. Deterioration of water quality, degradation of ecosystem and decline of bio-diversity occurred in Lake Chaohu, due to a great amount of industrial, agricultural and domestic sewage discharged into the lake, made the eutrophication become more and more serious. And the building of Chaohu Gate and Yuxi Gate enhanced the retention of phosphorus and speeds up the process of eutrophication (Shang and Shang, 2005). The climate of Lake Chaohu belongs to sub-tropical monsoon climates, the annual average rainfall is $1120 \mathrm{~mm}$ and the annual average temperature is 15$16{ }^{\circ} \mathrm{C}$ (Zheng et al., 2010).

\section{> SAMPLE COLLECTION}

From Nov. 2009 to Sep. 2010, in autumn, winter, spring, summer and after a longtime heavy rain, field investigations were carried out along the shoreline of Lake Chaohu. The number of sampling sites is 20 , which contain different types of shoreline such as agricultural field, grassland, woods, dilapidated embankment, rocky embankment and cement embankment. Surface sediments of littoral zones were obtained using a Peterson grab sampler and nearshore soils were also collected under the surface of the vegetation $10-20 \mathrm{~cm}$ at each site. The positions and types of sampling sites are shown in Figure 1 and Table I, and some important properties of these sediments and soils are present in Table II.

\section{> CHEMICAL ANALYSIS}

Soil samples were air-dried, sieve to $<2 \mathrm{~mm}$, and analyzed for following parameters:

Olsen-P were determined by $0.5 \mathrm{M} \mathrm{NaHCO}_{3}$ solution $(\mathrm{pH} 8.5)$ in an air-dried sample to extracting solution ratio 1:20 (Olsen et al., 1954), and algal available phosphorus (AAP) were determined by $0.1 \mathrm{M} \mathrm{NaOH}$ solution (Sharpley et al., 1991).

Organic matter $(\mathrm{OM})$ content was measured by the loss ignition in $550^{\circ} \mathrm{C}$ with muffle furnace for $3 \mathrm{~h}$.

Total phosphorus (TP), inorganic phosphorus (IP), and organic phosphorus (OP) were determined as the difference between ignited and nonignited soils extracted with $0.1 \mathrm{M} \mathrm{H}_{2} \mathrm{SO}_{4}$ (Saunders and Williams, 1955).

The air-dried sample was incubated with containing $0,1,5,10,20,30,40,50 \mathrm{mg} P \cdot \mathrm{L}^{-1}$ as $\mathrm{KH}_{2} \mathrm{PO}_{4}$ solution $25 \mathrm{~mL}$ in centrifuge tubes and shaken for $24 \mathrm{~h}$ at $25{ }^{\circ} \mathrm{C}$, centrifuged at $3000 \mathrm{rpm}$ for $20 \mathrm{~min}$, and analyzed for soluble reactive phosphorus (SRP). Phosphorus sorption behaviors were simulated by the Langmuir isothermal model, and the equilibrium phosphorus concentrations ( $\mathrm{EPC}_{0}$ ) were determined according to this model (Zhang et al., 2010).

Phosphorus sorption index (PSI) that could rapidly determine soil $\mathrm{P}$ sorption capacity were modified according to Bache and Williams (1971). When sample-solution ratio is 1:10, with $1.5 \mathrm{mg} \mathrm{P}$ being added to per $\mathrm{g}$ sample, $\mathrm{PSI}=\mathrm{Q} / \log C$, while $Q$ (mg $\mathrm{P} / 100 \mathrm{~g}$ sample) is 


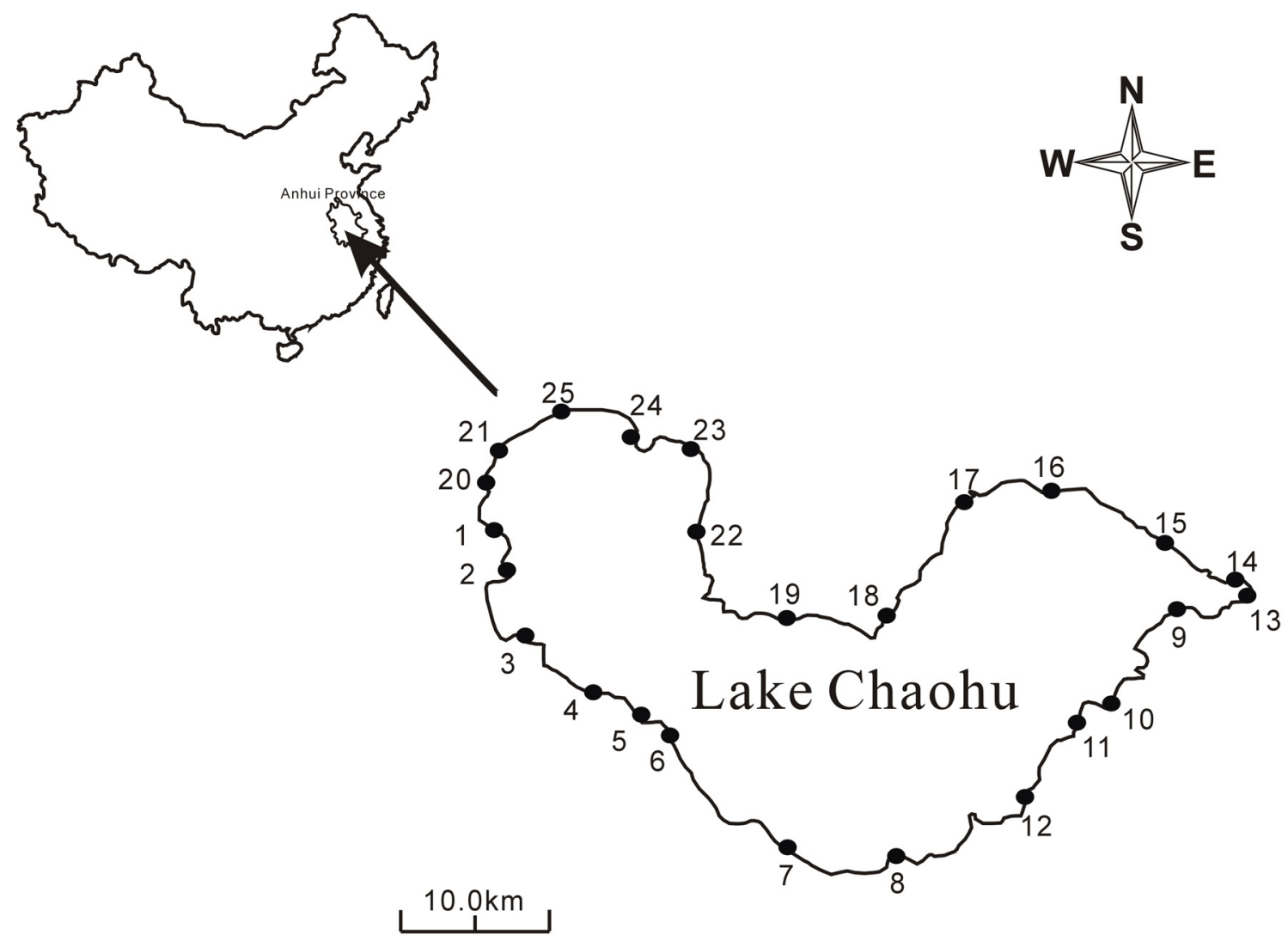

Figure 1

Map of lake Chaohu showing the sampling sites in soils and sediments along the shoreline (samples collection was broke off at sites 1, 2, 3, 20 and 25 due to the municipal projects).

Table I

Sampling sites with different land use patterns or bank types.

\begin{tabular}{c|c}
\hline Sampling site & Type of shoreline \\
\hline 4 & Cement embankment \\
5 & Grassland: Phalaris arundinacea Linn. and Rumexacetosa Linn. ${ }^{*}$ \\
6 & Agricultural field \\
7 & Woods \\
8 & Grassland: Cynodon dactylon Linn. ${ }^{*}$ \\
9 & Grassland: Erigeron acer Linn. ${ }^{*}$ \\
10 & Agricultural field \\
12 & Dilapidated embankment \\
13 & Dilapidated embankment \\
14 & Agricultural field \\
15 & Woods \\
16 & Artificial wetland \\
17 & Grassland: Cynodondactylon Linn. * \\
18 & Grassland: Cynodondactylon Linn. ${ }^{*}$ \\
19 & Cement embankment \\
21 & Agricultural field \\
22 & Reed: Phragmites communis Trin. * \\
23 & Rocky embankment \\
24 & Grassland: Cynodondactylon Linn. * \\
\hline
\end{tabular}

* Means primary dominant species. 
Table II

The properties of sediments and soils studied.

\begin{tabular}{|c|c|c|c|c|c|c|}
\hline & $\begin{array}{c}\mathrm{OM} \\
\left(\mathrm{mg} \cdot \mathrm{g}^{-1}\right) \\
\end{array}$ & $\begin{array}{c}\mathrm{TP} \\
\left(\mathrm{mg} \cdot \mathrm{kg}^{-1}\right) \\
\end{array}$ & $\begin{array}{c}\mathbb{I P} \\
\left(\mathrm{mg}^{\mathrm{kg}}{ }^{-1}\right) \\
\end{array}$ & $\begin{array}{c}\mathrm{OP} \\
\left(\mathrm{mg} \cdot \mathrm{kg}^{-1}\right) \\
\end{array}$ & $\begin{array}{r}\text { Olsen-P } \\
\left(\mathrm{mg} \mathrm{kg}^{-1}\right) \\
\end{array}$ & $\begin{array}{c}\text { AAP } \\
\left(\mathrm{mg}^{-1} \mathrm{~kg}^{-1}\right) \\
\end{array}$ \\
\hline & $244+1363$ & $25.92 \pm 254.0$ & $5.75 \pm 150.30$ & $90.17 \pm 121.84$ & $5.36 \pm 12.89$ & $76.17 \pm 120.59$ \\
\hline Soil & $28.97 \pm 14.61$ & $243.52 \pm 165.08$ & $151.03 \pm 131.20$ & $92.50 \pm 65.42$ & $11.10 \pm 14.53$ & $66.36 \pm 122.76$ \\
\hline
\end{tabular}

the amount of $P$ sorbed onto the sample, and $C\left(\mu \mathrm{mol} \cdot L^{-1}\right)$ is the $P$ concentration in the solutionafter equilibrium.

Sediment samples were processed in the same way as soil samples except Olsen-P and AAP were assayed in fresh samples (Olsen et al., 1954; Dorich et al., 1984).

Pearson correlation coefficients and nonlinear regression analysis were performed using SigmaPlot 2000 and SPSS 13.0 for windows.

\section{RESULTS AND DISCUSSION}

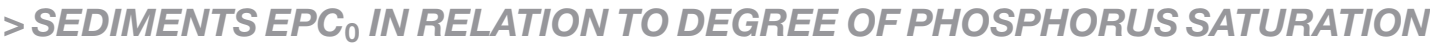 (DPS)}

The efficient detection of areas with a high risk of phosphorus loss requires a simple and universal soil test method that is cost effective and applicable in both industrialized and developing countries. Soils from areas which varied highly in land use and soil type were investigated regarding DPS as well as $\mathrm{EPC}_{0}$ and water-soluble phosphorus (WSP) as indicators for the potential of phosphorus loss. DPS, which reflects the actual state of phosphorus fertilization of soil, can be calculated from the easily accessible parameter WSP (Pothig et al., 2010). In the sediments along the littoral zone of Lake Chaohu, the DPS values can be defined as Olsen-P/Qmax,$A A P / Q_{\max }$ and IP/ $Q_{\max }$, and there existed significantly positive relationships between these DPS and $\mathrm{EPC}_{0}$ values. In addition, these relationships hold true when the $Q_{\max }$ was replaced by PSI that was a simple measure of $Q_{\max }$ (Indiati et al., 2002; Li et al., 2007) (Figure 2). Consistently, headwater ditch sediments had elevated $Q_{\max }$, while they had low $\mathrm{EPC}_{0}$ and DPS (Luo et al., 2009). More directly, the $\mathrm{EPC}_{0}$ values were positively related to some easily accessible parameters such as Olsen-P, AAP and IP (Figure 3). In conjunction, the surface soils have higher $\mathrm{EPC}_{0}$ and higher easily desorbed phosphorus $\left(\mathrm{NH}_{4} \mathrm{Cl}-\mathrm{P}\right)(\mathrm{Kerr}$ et al., 2011). The uptake and release of SRP is assumed to be driven by a differential between the $\mathrm{EPC}_{0}$ of the sediment and SRP concentration in the boundary layer. The bed sediments were found to act as net sources of SRP under the circumstance where $\mathrm{EPC}_{0}$ values were relatively high, as a result of deposition of particulates with high exchangeable phosphorus concentrations from diffuse sources or from effluents (Jarvie et al., 2005). Therefore, the contents of easily desorbed phosphorus (Olsen-P and AAP), absolute or relative to maximum sorption capacity, had an important implication to indicate the sediment functions acting as source or sink of phosphorus in lakes.

The correlations between EPC 0 and DPS or the easily desorbed phosphorus were statistically significant, although there is a large amount of scatters in the plots shown in Figures 2 and 3. Noticeably, the most striking outliers within the circle represented site 7 , site 8 and site 9, all of which had higher phosphorus sorption energy $(K)$ in sediments. At these sites higher DPS or the easily desorbed phosphorus were companied by lower $\mathrm{EPC}_{0}$. In parallel, the outliers within the square represented site 17 and site 19, the relatively lower $\mathrm{K}$ values were recorded in their sediments, where the less DPS or the easily desorbed phosphorus corresponded to higher $\mathrm{EPC}_{0}$. Thus, the sorption energy is an additional determinant for the sediment $\mathrm{EPC}_{0}$, has illustrated by significantly negative relationship between these two variables (Figure 4). Consistently, in a subtropical river in southeast Queensland, Australia, the sediments have lower $\mathrm{EPC}_{0}$ and higher phosphorus binding energy (Kerr et al., 2011). Furthermore, Two-phase 

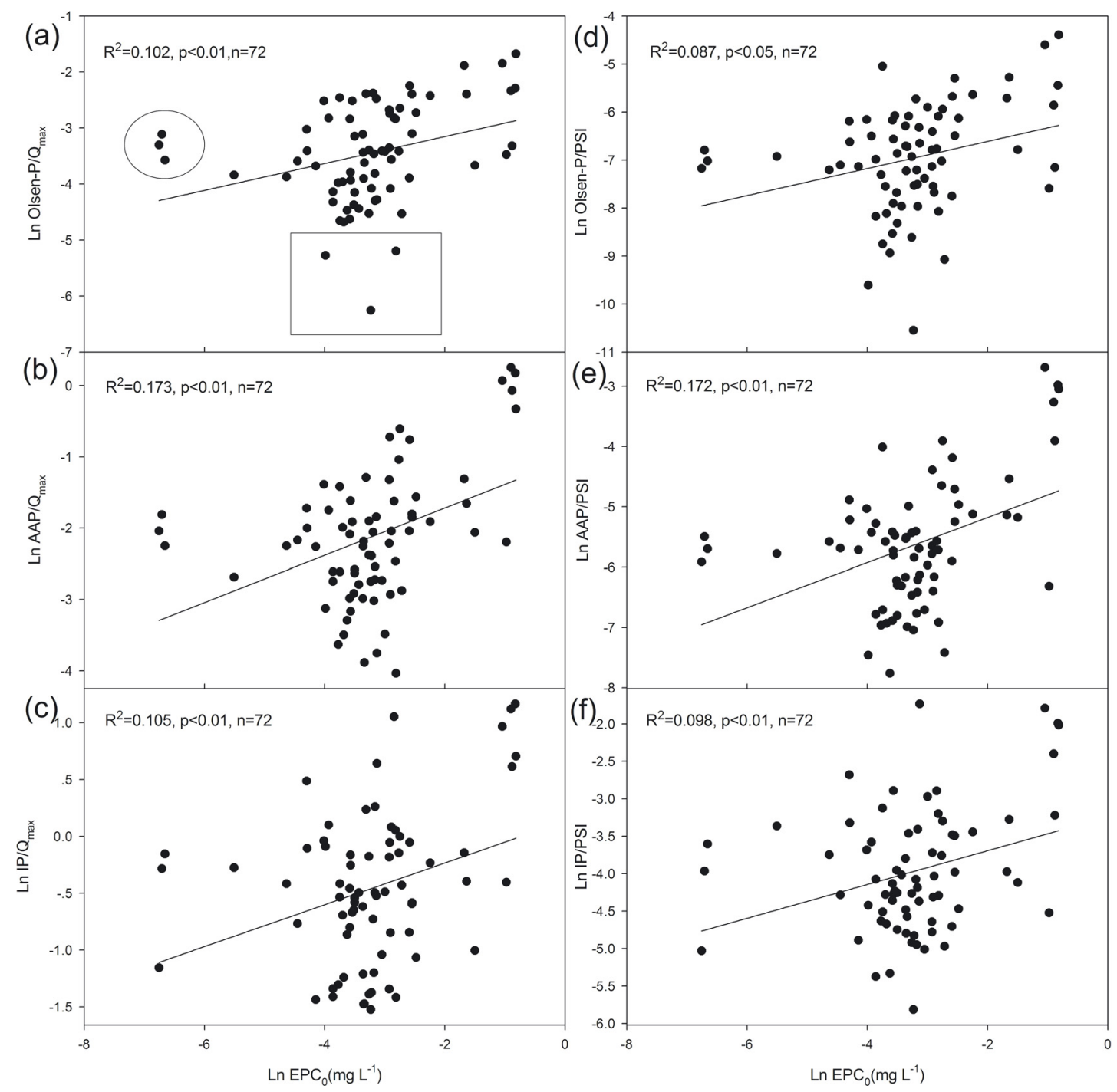

Figure 2

The relationships between EPC 0 and DPS, that was normalized by $Q_{\max }$ for (a), (b) and (c), $p<0.01$. DPS was also normalized with PSI, as illustrated by (d), $p<0.05$, (e) and (f), $p<0.01$.

olive mill waste (TPOMW) is a by-product of olive oil extraction, contains up to $90 \%$ organic matter, and maybe used as soil amendment. The TPOMW soil application decreased indices

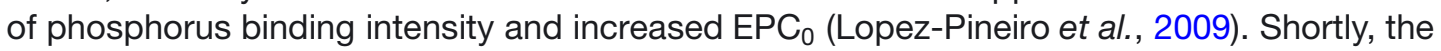
sorption energy is an independent key factor affecting $\mathrm{EPC}_{0}$, which may lead to departure from the ideal mode derived by the other driving force $\left(Q_{\max }\right.$ or DPS).

\section{> SEDIMENT DPS AS AFFECTED BY THE SOIL OM}

As shown in Table III, there existed significantly positive relationships between the nutrient parameters (IP, TP and OM) in the sediments and those in the shoreline soils. So the shoreline was suggested to be a nutrient source for the sediment, which greatly modifies its phos-

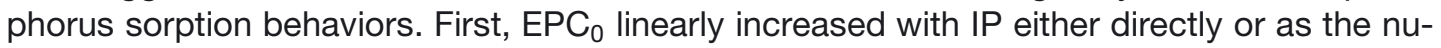
merator of DPS. In the same time, as shown in Figure 5, there was a significant positive relationship between TP and IP, although there were scatters that represented the most polluted site (site 24) with cement embankment near the city (Hefei City). The lake basin near 


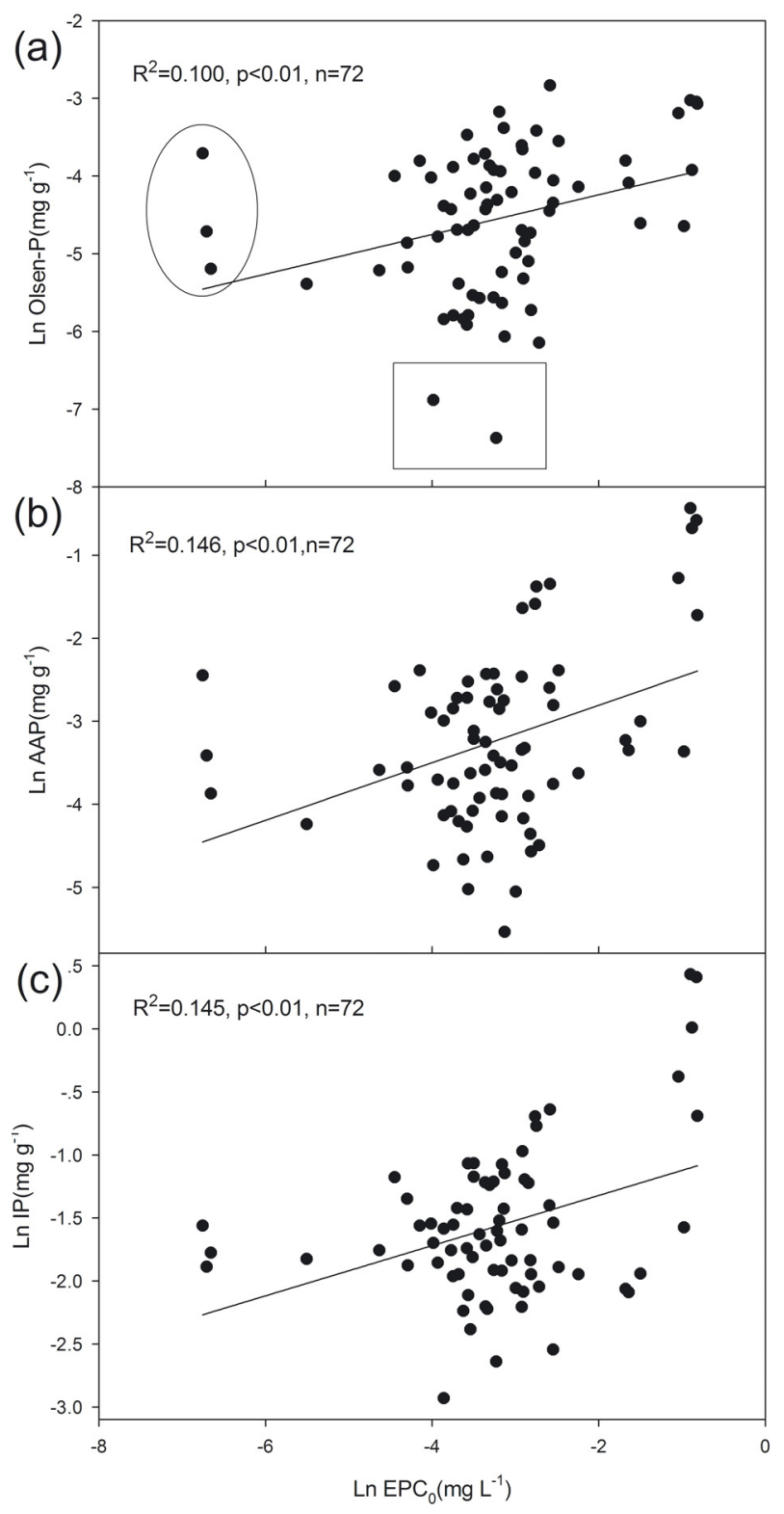

Figure 3

The relationships between $E P C_{0}$ values and the contents of different phosphorus species such as Olsen$P(\mathrm{a}), A A P(b)$ and IP (c) in the sediment, $p<0.01, n=72$.

the urban area always had the markedly higher phosphorus content in the sediments (Zhou et al., 2008). Second, the OM was significant proportional to the Olsen-P (Figure 6), thus, it was an important contributes to bioavailable phosphorus in the lake. Consistently, there was a substantial increase in Olsen-P under organic treatments in soils (Datta et al., 2010). Moreover, the SRP fraction could be estimated by soil Olsen-P (Borda et al., 2010). Both soluble and particulate phosphorus flowed into the Donana wetlands through runoff. A gradient in the SRP concentrations was found from the littoral to the pond center following a $108.5 \mathrm{~mm}$ storm. The SRP concentration was 100 times higher $2 \mathrm{~m}$ from the shoreline than it was at the pond center. The highest SRP concentration was leached from the fine, organic-matter-rich soil fraction from uplands. The incoming phosphorus concentrations to Donana wetlands vary greatly from year to year according to changes in hydro-meteorological conditions (Serrano et al., 1999). The heterogeneity in the above environmental factors may explain the scatters occurred in our plot (Figure 6). Furthermore, the land use patterns along the shoreline of Lake 


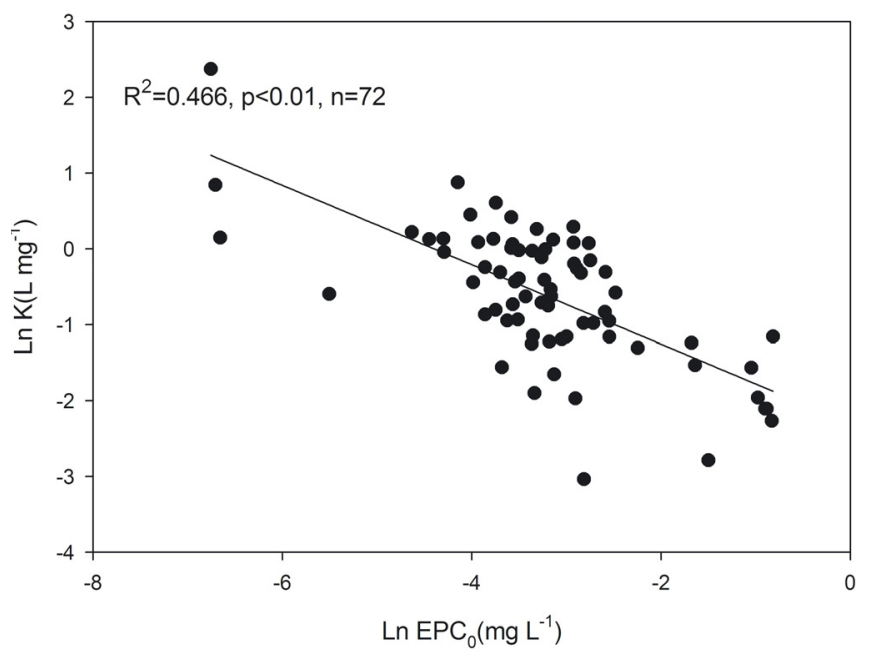

Figure 4

The relationship between $E P C_{0}$ values and sorption energy $(K)$ in the sediment, $p<0.01, n=72$.

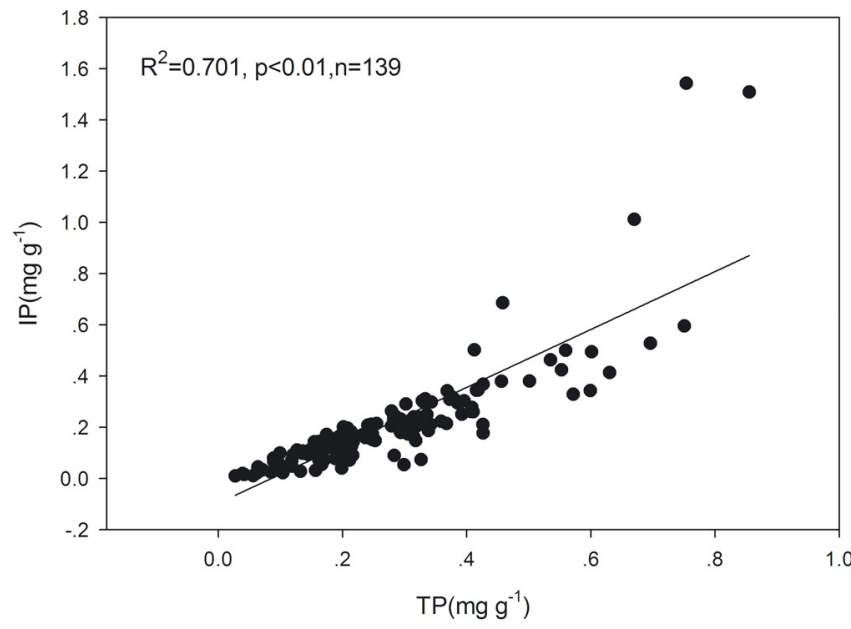

Figure 5

The relationship between the contents of TP and IP in the soil and sediment, $p<0.01, n=139$.

\section{Table III}

The correlations of different parameters between sediments and soils.

\begin{tabular}{|c|c|c|c|c|c|}
\hline & Olsen-P A & $\mathrm{AAP}^{\mathrm{A}}$ & $\mathrm{IP}^{\mathrm{A}}$ & $\overline{T P A}$ & $\mathrm{OM}^{\mathrm{A}}$ \\
\hline Olsen-P B & 0.1748 & & & & \\
\hline $\mathrm{AAP}^{\mathrm{B}}$ & & 0.2910 & & & \\
\hline $\mathrm{IP}^{\mathrm{B}}$ & & & $0.0010^{*}$ & & \\
\hline $\mathrm{TP}^{\mathrm{B}}$ & & & & $0.0040^{*}$ & \\
\hline $\mathrm{OM}^{\mathrm{B}}$ & & & & & $0.0002^{*}$ \\
\hline
\end{tabular}

\footnotetext{
${ }^{A}$ Means the parameter in the sediment of littoral zone.

${ }^{B}$ Means the parameter in the soil of shoreline.

* Means significant correlation $(p<0.01)$.
} 


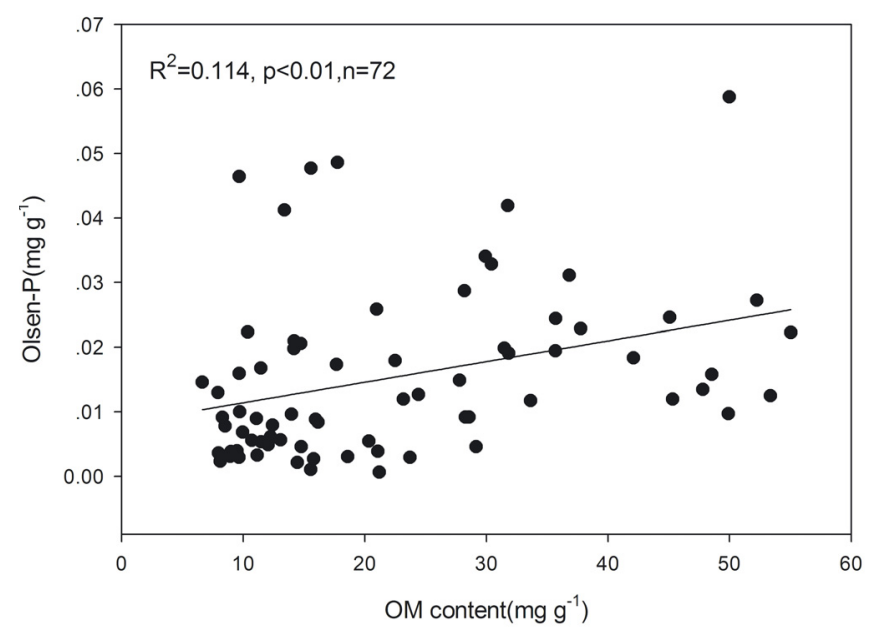

Figure 6 The relationship between the contents of OM and Olsen-P in the sediment, $p<0.01, n=72$.
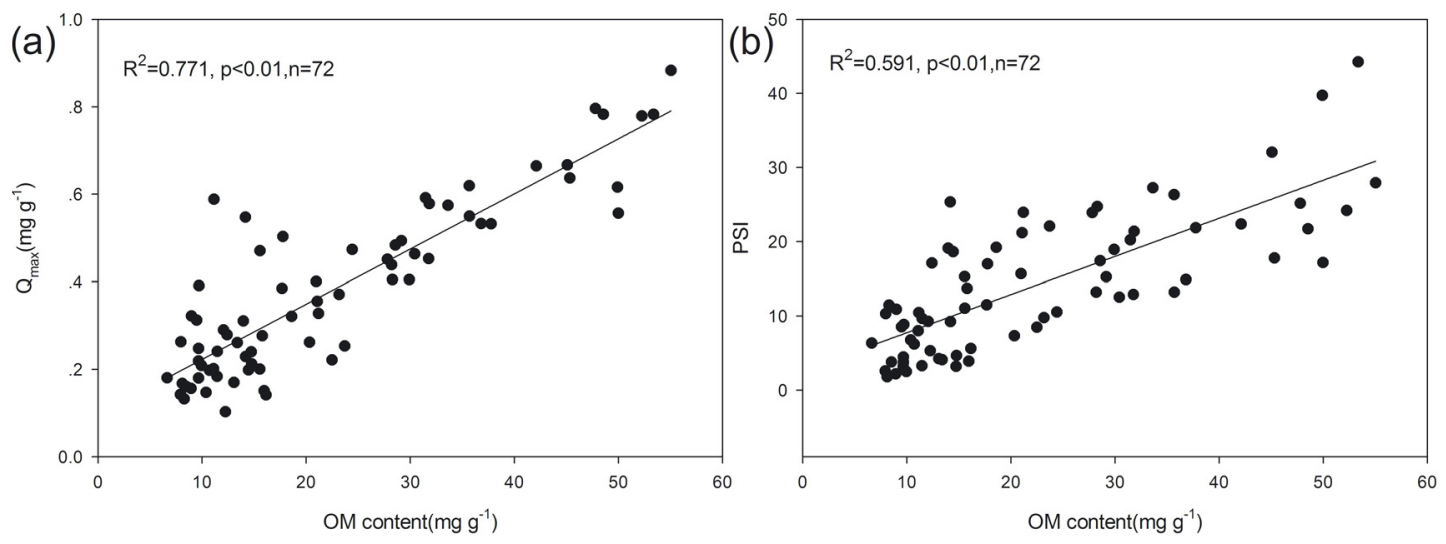

Figure 7

The relationships between OM content and $Q_{\max }$ (a) as well as $P S I$ (b) in the sediment, $p<0.01, n=72$.

Chaohu are diverse, together with the nature and amount of the soil OM, which may interrupt the ideal relationship between OM and Olsen-P. It was noted that the Olsen-P content of soil increased with the rate of organic fertilizer application, with the rate being the most effective and the nature of fertilizer the least effective (Mohammadi et al., 2009). On the other hand, as shown in Figure 7, the $Q_{\max }$ and PSI linearly increased with the OM, which was in conjunction with other observations (Subramaniam and Singh, 1997; Tripathi and Praveen-Kumar, 2000; McDowell and Sharpley, 2001; Li et al., 2007; Troitino et al., 2008). As the ratio of Olsen-P and $Q_{\max }$ or PSI, DPS depends on the extents to which $Q_{\max }$ and Olsen-P increase respectively. Additionally, as shown in Figure 8, the OM had another positive effect on phosphorus sorption by significantly enhancing the sorption energy. Consistently, headwater ditch sediments had elevated values of $Q_{\max }$ and $K$ (Luo et al., 2009). The $K$ value and maximum buffer capacity were highly and positively correlated to organic C (Subramaniam and Singh, 1997). However, the soil $\mathrm{OM}$ was not the only factor controlling the $K$ value, when plotted with each other there must be some scatters (Figure 8). For example, in soil of the Minnesota River Basin, the $K$ value was highly correlated with soil $\mathrm{pH}$, clay content, and OM content (Fang et al., 2005). Moreover, soil phosphorus sorption data were well described by a binary Langmuir equation which considers two groups of sorption sites that differ in their phosphorus bonding energies. High energy sites are on Al-oxi-hydroxides or small Al-substituted Fe-oxides and, to a lesser extent, on poorly ordered Fe-oxi-hydroxides. On the other hand, the phosphorus sorption capacity of low energy sites is mainly related to clay content, and it increases as 


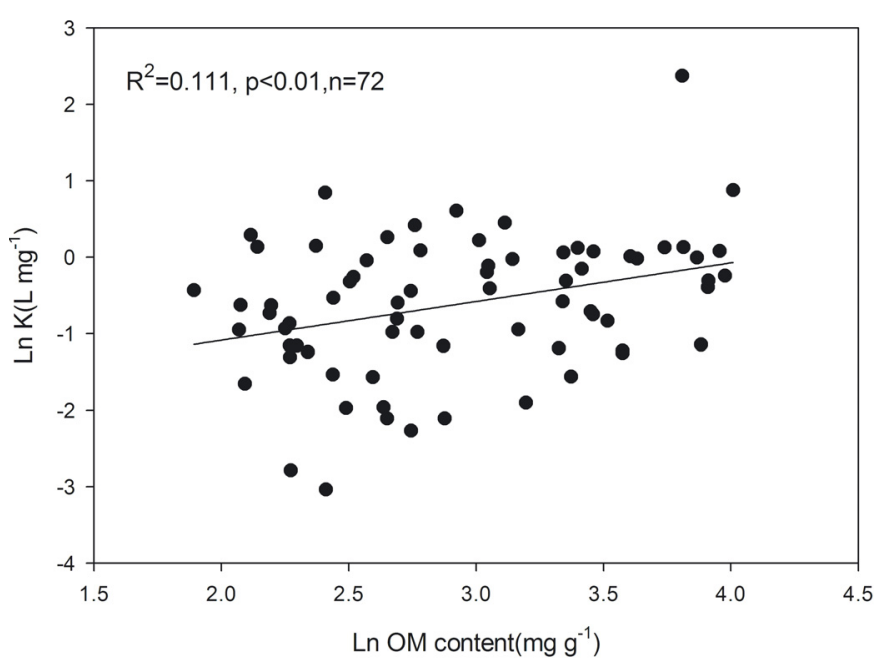

Figure 8

The relationship between OM content and sorption energy $(K)$ in the sediment, $p<0.01, n=72$.

$\mathrm{pH}$ decreases. These sites are also positively correlated with organic carbon and poorly crystalline Fe-oxi-hydroxides. However, as these two variables are closely correlated with each other, OM is likely to be considered as an indirect factor of phosphorus fixation through its association with Fe-oxi-hydroxides and not as an important source of phosphorus sorption sites (Quang et al., 1996). Thus, OM modified the sediment $\mathrm{EPC}_{0}$ values in complicated ways by exerting positive and simultaneously negative influences on DPS, and so did further the shoreline soils by discharging both inorganic phosphate and OM into lakes.

\section{> LINKS BETWEEN THE SOIL OM AND LAND USE PATTERNS}

It is well known that the $\mathrm{EPC}_{0}$ value is a key parameter indicating the sediment function to act as phosphorus source or sink. Based on the seasonal EPC $\mathrm{E}_{0}$ data on average (Figure 9), the sampling sites could be roughly divided into 4 groups: Group A (site 7, 14, 9, 8) with the $\mathrm{EPC}_{0}<0.03 \mathrm{mg} \cdot \mathrm{L}^{-1}$, Group $\mathrm{B}$ (site $\left.11,6,5,22,17,19,4\right)$ with the $\mathrm{EPC}_{0}$ ranging from 0.03 to $0.10 \mathrm{mg} \cdot \mathrm{L}^{-1}$, Group $\mathrm{C}$ (site 21 and 23 ) with the $\mathrm{EPC}_{0}$ ranging from 0.12 to $0.15 \mathrm{mg} \cdot \mathrm{L}^{-1}$, and Group D (site 24) with the EPC $0>0.40 \mathrm{mg} \cdot \mathrm{L}^{-1}$. Obviously, Group D (cement embankment) showed the weakest phosphorus buffering capacity, while the Group A (woods and grassland) had the strongest one. Furthermore, belonging to Group A, site 9 (Fleabane) decreased its $\mathrm{EPC}_{0}$ to larger extent after raining compared with the other sites in the group (Figure 10). Thus, Fleabane (Erigeron acer Linn., a common name for some flowering plants in the family Asteraceae) is a suitable grass species to inhabit in the shoreline soil for phosphorus buffering. The mechanisms could be explained in terms of OM. In the four different seasons, and among all the sampling sites in the littoral zone, site 9 irrespectively gave the lowest values of DPS (Figure 9). In fact, compared to site 11 representing dilapidated embankment and site 17 representing the soils covered by Cynodon (Cynodon dactylon Linn., a genus of nine species of grasses, Gramineae), site 9 showed markedly higher sediment IP content in all the seasons studied, while it had the highest OM contents in parallel, thereby giving the lowest DPS and smaller $\mathrm{EPC}_{0}$ values that was still lower than those in site 11 and site 17. The OM derived from this grass species may greatly strengthen the phosphorus buffering capacity by enhancing sediment $Q_{\max }$ values. In conjunction, various adsorption-desorption parameters were significantly related with the phosphorus uptake of different summer (rice, maize, soybean) and winter (wheat, berseem and raya) crops. Adsorption maxima, desorption maxima and maximum buffering capacity are the major parameters governing phosphorus availability in soils (Singh et al., 2006). The phosphorus adsorption maximum and the maximum phosphate buffering capacity for $80-100 \mathrm{~cm}$ were greater in the grain crop soil than the horticultural 

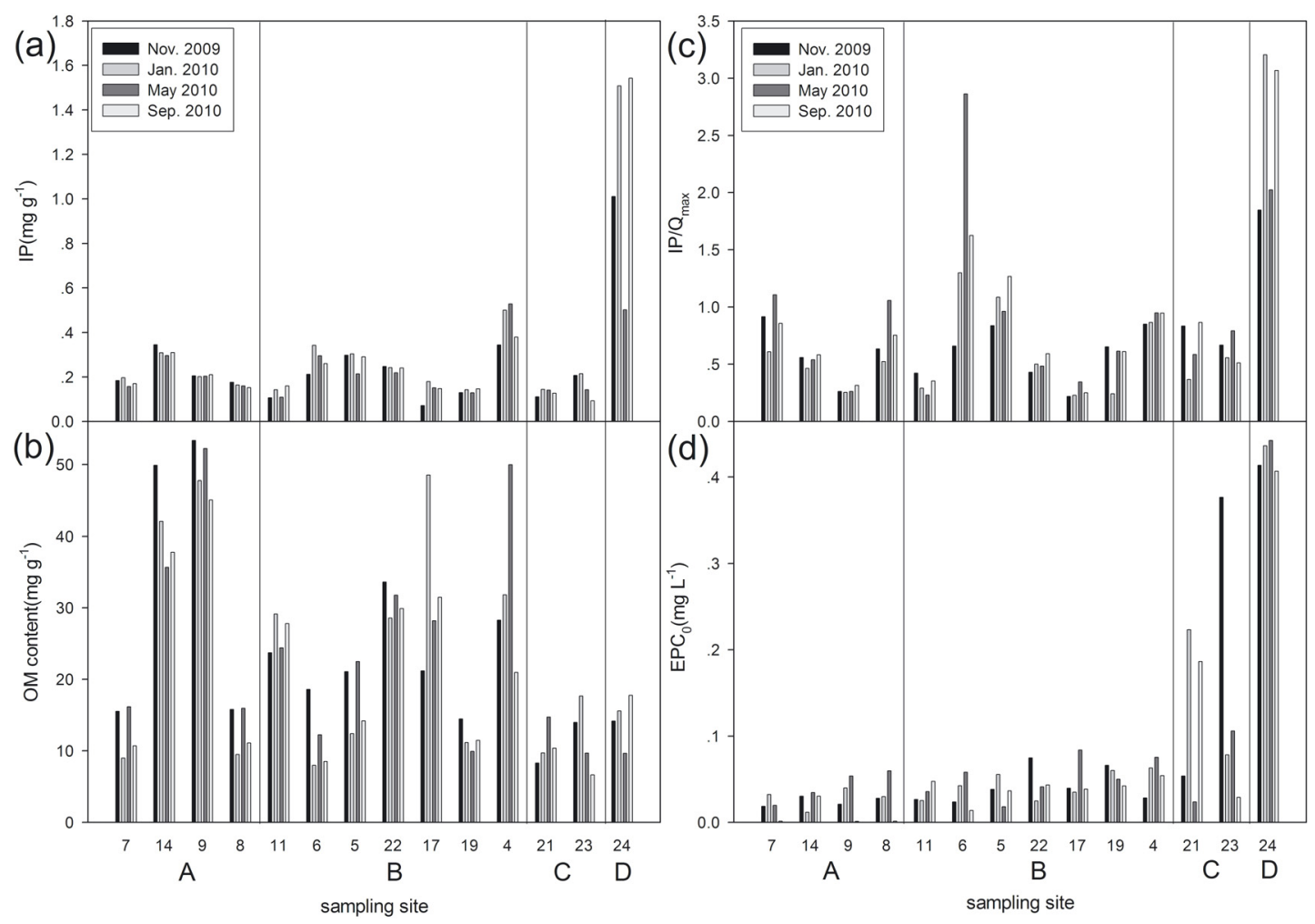

Figure 9

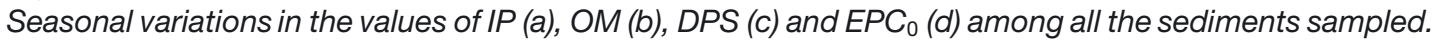

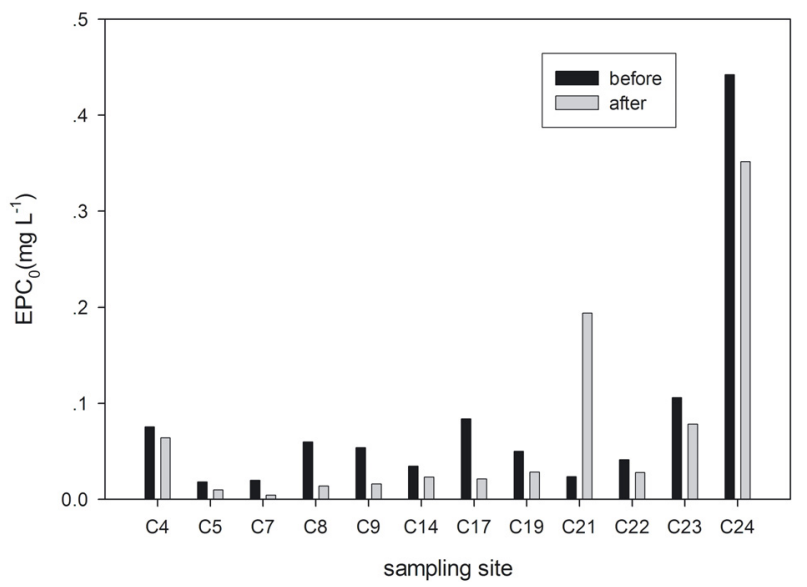

\section{Figure 10}

Variations of $E P C_{0}$ values in the sediments before and after the rainy season.

soils (Wang and Hou, 2004). What is more, incorporation of crop residues increased phosphorus adsorption maxima as well as resistance to phosphorus release in soils (Varinderpal-Singh et al., 2006). Besides, site 8 was belong to Group A, and its EPC 0 greatly decreased also after raining (Figure 10). However, this grass species (Cynodon) occurred at many sites scattering into the 3 groups (A, B, and C). In details, the $\mathrm{EPC}_{0}$ value was significantly higher at site 23 (the Group C) inhabited by the same grass species, but it only slightly decreased after raining (Figure 10). So, the capacity of this species to buffer phosphorus seemed to be unstable. Finally, site 21 inhabited by reed had significant higher $\mathrm{EPC}_{0}$ in the Group C. Noticeably, as shown in Figure 10, after the rainy season during which strong runoff entered the lake from 
the bank, the sediment $\mathrm{EPC}_{0}$ in site 9 significantly decreased while that in site 21 significantly increased. Overall, the cement embankment is the least infective for phosphorus buffering, and the manners of plants modifying phosphorus sorption behavior of sediment are species specific. Fleabane is the suitable species, while the functions of reed as a major wetland plant to control sediment phosphorus release deserve to be further studied, it might have some adverse effects.

\section{CONCLUSIONS}

Seasonal data on status on the sorption behavior of phosphorus were collected from littoral zone sediments and adjacent soils representing different patterns of land use (agricultural field, grassland, woods) and bank types (dilapidated embankment, rocky embankment and cement embankment) at 20 sites along shoreline of a Chinese large shallow lake (Lake Chaohu) starting from Nov. 2009 to Sep. 2010. Theoretical simulation using the Langmuir model and statistical analysis were made to link land use with phosphorus buffering capacity in sediments. The main findings are:

1. Adjacent to shoreline, land soil and lake sediment were significantly related in terms of inorganic phosphorus, total phosphorus and organic matter.

2. $E P C_{0}$ values were linear functions of DPS and contents of some inorganic phosphorus species (Olsen-P and AAP) in the sediment.

3. Organic matter not only provided sediment with inorganic phosphorus (Olsen-P and AAP), but also gave linear rises to its $Q_{\max }$ and sorption energy, thereby showing a complicated influence on DPS together with $\mathrm{EPC}_{0}$.

4. The land soil covered by Fleabane always corresponded to the sediment that generally had the lower $\mathrm{EPC}_{0}$ values.

This study revealed the linkage between land use and phosphorus buffering capacity of sediments along shoreline of a large lake. In details, inorganic phosphorus and organic matter

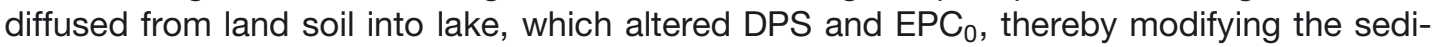
ment functions to act as source or sink of phosphorus. It also suggested that easily accessible parameters (Olsen-P, AAP and DPS) can be used to estimate phosphorus buffering capacity in sediment and suitable pattern of land use (coverage with Fleabane), which is helpful for the remediation, construction and management of shoreline in large eutrophic lakes.

\section{ACKNOWLEDGEMENTS}

This work was supported by these grants: the National Key Basic Research and Development Program (2008CB418005), Major Science and Technology Program for Water Pollution Control and Treatment (2009ZX07106-001 and 2008ZX07103-004) and Sino-Hungary Bilateral S\&T Cooperation (2008-333-4-7). The authors would like to thank Mr. Wei Xing for his careful work on identification of dominant species. The thanks will also go to Mr. Xiaoke Zhang for his help in the sampling collection.

\section{REFERENCES}

Bache B.W. and Williams E.G., 1971. Phosphate sorption index for soils. J. Soil Sci., 22, 289-301.

Borda T., Withers P.J.A., Sacco D., Zavattaro L. and Barberis E., 2010. Predicting mobilization of suspended sediments and phosphorus from soil properties: a case study from the north west Po valley, Piemonte, Italy. Soil Use Manage., 26, 310-319.

Datta S.P., Rattan R.K. and Chandra S., 2010. Labile soil organic carbon, soil fertility, and crop productivity as influenced by manure and mineral fertilizers in the tropics. J. Plant Nutr. Soil Sci., 173, 715-726. 
Dorich R.A., Nelson D.W. and Sommers L.E., 1984. Availability of phosphorus to algae from eroded soil fractions. Agric. Ecosyst. Environ., 11, 253-264.

Fang F., Brezonik P.L., Mulla D.J. and Hatch L.K., 2005. Characterization of soil algal bioavailable phosphorus in the Minnesota river basin. Soil Sci. Soc. Am. J., 69, 1016-1025.

Hiradate S. and Uchida N., 2004. Effects of soil organic matter on pH-dependent phosphate sorption by soils. Soil Sci. Plant. Nutr., 50, 665-675.

Indiati R., Trujillo I. and Gutierrez F., 2002. Characterization of P adsorption properties of some agricultural volcanic soils from Canary Islands, Spain. Trop. Agric., 79, 254-259.

Janardhanan L. and Daroub S.H., 2010. Phosphorus sorption in organic soils in south Florida. Soil Sci. Soc. Am. J., 74, 1597-1606.

Jarvie H.P., Jurgens M.D., Williams R.J., Neal C., Davies J.J.L., Barrett C. and White J., 2005. Role of river bed sediments as sources and sinks of phosphorus across two major eutrophic UK river basins: the Hampshire Avon and Herefordshire Wye. J. Hydrol., 304, 51-74.

Kerr J.G., Burford M., Olley J. and Udy J., 2011. Phosphorus sorption in soils and sediments: implications for phosphate supply to a subtropical river in southeast Queensland, Australia. Biogeochemistry, 102, 73-85.

Li M., Hou Y.L. and Zhu B., 2007. Phosphorus sorption-desorption by purple soils of China in relation to their properties. Aust. J. Soil Res., 45, 182-189.

Lopez-Pineiro A., Cabrera D., Pena D., Albarran A. and Nunes J.M.R., 2009. Phosphorus adsorption and fractionation in a two-phase olive Mill waste amended soil. Soil Sci. Soc. Am. J., 73, 1539-1544.

Luo Z.X., Zhu B., Tang J.L. and Wang T., 2009. Phosphorus retention capacity of agricultural headwater ditch sediments under alkaline condition in purple soils area, China. Ecol. Eng., 35, 57-64.

McDowell R.W. and Sharpley A.N., 2001. A comparison of fluvial sediment phosphorus (P) chemistry in relation to location and potential to influence stream P concentrations. Aquat. Geochem., 7, 255-265.

Mohammadi S., Kalbasi M. and Shariatmadari H., 2009. Cumulative and residual effects of organic fertilizer application on selected soil properties, water soluble P, Olsen-p and P sorption index. J. Agric. Sci. Technol., 11, 487-497.

Olsen S.R., Cole C.V., Watanabe F.S. and Dean L.A., 1954. Estimation of available phosphorus in soils by extraction with sodium bicarbonate. In: USDA Circular, USDA, Washington DC, 939 p.

Pothig R., Behrendt H., Opitz D. and Furrer G., 2010. A universal method to assess the potential of phosphorus loss from soil to aquatic ecosystems. Environ. Sci. Pollut. R., 17, 497-504.

Quang V.D., Thai V.C., Linh T.T.T. and Dufey J.E., 1996. Phosphorus sorption in soils of the Mekong delta (Vietnam) as described by the binary Langmuir equation. Eur. J. Soil Sci., 47, 113-123.

Saunders W.M.H. and Williams E.G., 1955. Observations on the determination of total organic phosphorus in soils. J. Soil Sci., 6, 254-267.

Serrano L., Burgos M.D., Diaz-Espejo A. and Toja S., 1999. Phosphorus inputs to wetlands following storm events after drought. Wetlands, 19, 318-326.

Shang G.P. and Shang J.C., 2005. Causes and control countermeasures of eutrophication in Chaohu lake, China. Chinese Geogr. Sci., 15, 348-354.

Sharpley A.N., Troeger W.W. and Smith S.J., 1991. The Measurement of bioavailable phosphorus in agricultural runoff. J. Environ. Qual., 20, 235-238.

Singh V., Dhillon N. and Brar B., 2006. Influence of long-term use of fertilizers and farmyard manure on the adsorption-desorption behaviour and bioavailability of phosphorus in soils. Nutr. Cycl. Agroecosys., 75, 67-78.

Stutter M.I. and Lumsdon D.G., 2008. Interactions of land use and dynamic river conditions on sorption equilibria between benthic sediments and river soluble reactive phosphorus concentrations. Water Res., 42, 4249-4260.

Subramaniam V. and Singh B.R., 1997. Phosphorus supplying capacity of heavily fertilized soils .1. Phosphorus adsorption characteristics and phosphorus fractionation. Nutr. Cycl. Agroecosys. , 47, 115-122.

Tripathi K.P. and Praveen-Kumar, 2000. Phosphate adsorption in aridisols in relation to soil properties. Ann. Arid. Zone, 39, 131-135.

Troitino F., Gil-Sotres F., Leiros M.C., Trasar-Cepeda C. and Seoane S., 2008. Effect of land use on some soil properties related to the risk of loss of soil phosphorus. Land Degrad. Dev., 19, 21-35. 
Varinderpal-Singh, Dhillon N.S. and Brar B.S., 2006. Effect of incorporation of crop residues and organic manures on adsorption/desorption and bio-availability of phosphate. Nutr. Cycl. Agroecosys., 76, 95-108.

Wang X.M. and Hou Y.L., 2004. Effect of continuous vegetable cultivation on phosphorus levels of fluvoaquic soils. Pedosphere, 14, 171-176.

Xu M.Q., Cao H., Xie P., Deng D.G., Feng W.S. and Xu H., 2005. The temporal and spatial distribution, composition and abundance of Protozoa in Chaohu lake, China: Relationship with eutrophication. Eur. J. Protistol., 41, 183-192.

Zhang W., Faulkner J.W., Giri S.K., Geohring L.D. and Steenhuis T.S., 2010. Effect of soil reduction on phosphorus sorption of an organic-rich silt loam. Soil Sci. Soc. Am. J., 74, 240-249.

Zheng L.G., Liu G.J., Kang Y. and Yang R.K., 2010. Some potential hazardous trace elements contamination and their ecological risk in sediments of western Chaohu lake, China. Environ. Monit. Assess., 166, 379-386.

Zhou Y.Y., Song C.L., Cao X.Y., Li J.Q., Chen G.Y., Xia Z.Y. and Jiang P.H., 2008. Phosphorus fractions and alkaline phosphatase activity in sediments of a large eutrophic Chinese, lake (lake Taihu). Hydrobiologia, 599, 119-125. 